\title{
An Analysis of the Impact of Boko Haram insurgents on Business Entrepreneurship Environment in Nigeria
}

\author{
Associate Prof. Dr. Muhammad Fuad Othman \\ School of International Studies, Universiti Utara Malaysia \\ Imaji Zekeri Ojonumiache Sule \\ PhD Candidate, School of International Studies, Universiti Utara Malaysia; Imaji_sule@yahoo.com \\ Prof. Emeritus Dr. Ranjit Singh a/l Darshan Singh \\ School of International Studies, Universiti Utara Malaysia
}

\section{Doi:10.5901/ajis.2015.v4n3p37}

\section{Abstract}

\begin{abstract}
This paper will examine the impact of boko haram on business entrepreneurship environment in Nigeria. Since the emergence of the group in 2002, the business environment has not been conducive for business related activities due to bombings and attacks on the people. An exploratory method of data collection was carried out using secondary data such as news papers, journals and online information. the findings revealed that businesses no longer takes place in the affected areas such as the northeast part of Nigeria because markets were closed, banking services not rendered or hours of services reduced. The paper then recommends that the source of income; training; and supply of weapons to Boko Haram be blocked by the Nigerian government and also engage in human security such as job creation; and provision of infrastructural facilities so as to combat the activities of the sect and thereby creating enabling environment for business and entrepreneurship to flourish.
\end{abstract}

Keywords: Boko Haram, Business, Entrepreneurship and Impact.

\section{Introduction}

Insurgencies has been as old as civilization but became most prominent after the September 112001 bombings of the United States by Al-Qaeda. The bombings were carried out on world trade centre which has adverse effects on the business activities of America and globally (Rogan 2007).

Other insurgent's activities were carried out by other groups such Al-Qaeda in the Islamic Maghreb of Algeria and Al-Shabaab of Somalia which also affects the business as well the economy of those countries.

Boko Haram started as a small radical Sunni Islamic organization with preaching and a limited support from among the Sufi Islamic communities in the Northeastern part of Nigeria, the anti-western ideology of the Boko Haram terrorist group, earn it the concern about its potential relationship with other groups such as Sunni extremist or terrorist groups elsewhere, including al-Qaeda as well as al-Qaeda affiliates such as al-Qaeda in the Islamic Maghreb (AQIM) in Algeria and Mali and Al-Shabaab in Somalia. These groups bomb shopping malls; airports and business areas, thereby making business environment to collapse (Reuters, 2013).

Like an array of contemporary terrorist groups throughout history, Boko Haram started domestically, but over time, its operational capabilities and impact have grown, spreading like cancer from Borno state to neighboring states such as Yobe, Adamawa, Bauchi, Kano and even to Abuja, the Federal Capital of Nigeria and beyond.

It Attacks Military formations such as army barracks, police stations, immigration offices, schools and prisons, and more seriously, killing and injuring of both Christians, Muslims, women and children and most recently abduction and killing of school children. Markets and motors parks were constantly attacked and banks frequently robbed thereby forestalling business activities in the affected areas (This day News paper, 2012).

This paper therefore will examine the impact of Boko Haram insurgents on the business environment in Nigeria and then recommend how the negative impact will be reduced to give room for business activities to survive. 


\section{Research Questions of the Paper}

This paper seeks to answer the following questions:-

1. How is the activities of Boko Haram distorting entrepreneurship environment in Nigeria?

2. What then can be done to curtail the incidents of this group to create an enabling environment for business and other economic activities to take place conveniently?

\section{Objective of the Paper}

a) To examine how the activities of Boko Haram has distorted the entrepreurship environment in Nigeria.

b) To explore what to be done to curtail the activities of Boko Haram to make business and other economic activities to effectively take place.

\section{Significance of the Study}

This study therefore attempt to examined the activities of Boko Haram and its distortion of the business entrepreneurship environment in Nigeria and subsequently, means of combating the menace of the insurgents shall be discussed to bring about the conducive environment that will bring about stable business enterprises.

\section{Literature on the Emergence of Boko Haram Insurgent in Nigeria}

The early members of Boko Haram were people such as Aminu Tashen llimi, who integrally involved in the founding of the early evolution of Boko Haram (Gusau, 2009). However, there are differences in opinion over the precise date and conditions under which the group that became known as Boko Haram was first established, but a senior Nigerian military officer has suggested that the group has existed in some form or another since 1995 (Onuoha,2010). While others have written that it was founded in 2003 or 2004. A Nigerian reporter Isioma Madike contends that the group began in 1995 as Sahaba under the leadership of the conservative Islamist cleric Lawan Abubakar, who later left for the University of Medina in Saudi Arabia for further studies (Madike,2011). Isa Umar Gusau suggests that the origins of the group can be traced to a group of Muslim students who dropped out of the University of Maiduguri around 2002 (Gusau,2009) Despite the existence of various conflicting accounts, it is agreed by most observers that in 2002, a Muslim cleric by name Ustaz Mohammed Yusuf, established a religious complex with a mosque and an Islamic boarding school in Maiduguri in Borno state, along with a prayer group which he called "Jama'atul Alhul Sunnah Lidda'wati wal Jihad" loosely translated from Arabic as "people committed to the propagation of the Prophet's teachings and jihad (Chothia,2011). The same group is better known by its Hausa and Arabic name as Boko Haram, meaning "Western education is sinful" (Adesoji, 2009, p: 100).

Teachers at this school have been known to abuse these children; in some cases taking a portion of whatever people gives to them, and in other cases using them as foot soldiers in religious clashes (Saidu, 2011). This was the kind of school that was established by MuhammedYusuf.

The present ongoing terrorist attacks in Nigeria by Boko Haram is both of religion and political in nature. Mantzikos (2010) in his work titled "The Absence of a state in Northern Nigeria: The case of Boko Haram" Argued that:

At the moment, there is an external dimension to the rise of terrorism in Nigeria. An Islamic terrorist group called Jama'atu Ahlus-Sunnah Lidda'Awati wal Jihad- meaning 'People committed to the propagation of the Prophet's Teachings and Jihad'. The sect is popularly called 'Boko Haram'- a combination of the Hausa word, 'Boko' meaning 'western education' and the Arabic word 'Haram' meaning forbidding or sin which figuratively means 'Western education is a sin' (Mantzikos, 2010, p.1).

Mantzikos further maintained that: "Boko Haram which started operation in the year 2002 as a domestic Islamic group metamorphosed in 2011 into international terrorism in its tactics, due its collaboration with outside terrorist groups" The outside terrorist organizations includes al Qaeda in the Islamic Maghreb (AQIM) and Harakat al-Shabaab alMujahideen (Al-Shabaab), which are all affiliates of al-Qaeda terrorist network.

The first leader of the group was Mohammed Ali in Maiduguri of Borno state in the Northern part of Nigeria, it was during his time that the group declared Maiduguri city and Islamic establishment as intolerably corrupt and irredeemable, hence it embark on hijra (a withdrawal along the lines of the Prophet Mohammed's withdrawal from Mecca to Medina). It moved to a village called Kanama, in Yobe state. The group called on Muslims to join the group and return to a life under 
'true Islamic law, with the aim of making a more perfect society away from the corrupt establishment (Walker, 2012:2).

Walker further states that in December 2003, the group clashed over a fishing pond rights with the community where they flew to, the group had clashed with the police, at the first instance, the group overpowered the police and took their weapons. The Nigerian armies later intervened, seize the group's mosque and subsequently overpowered the group and killed almost 70 members of the group including their leader, Mohammed Ali.

Walker (2012, p.4) reports a bloodier event that took place between the police and the Boko Haram sect in July 2009. He stated that the group was travelling en masse to the funeral of a fellow member where they were stopped by the police traffic officers, who were enforcing the tightened restriction on motorcycle helmets and an argument ensued. A member of the group was then reported to have fired on the police, injuring several of them. The group further attacked police stations in Bauchi and Yobe state, killing scores of police officers. After the episode, Yusuf released several video sermons in which he explicitly threatened the state and the police with violence.

The above event led the Bauchi government to crack down on the group, arresting more than seven hundred members. In Maiduguri, the police surrounded the group's mosque, but members of the sect managed to break out and for three days they had the run of the town. They roam the city acting independently, fighting police when they come across them and killing Muslims and Christians indiscriminately.

Walker further narrated that the police eventually regained control of Maiduguri, and embarked on bloody purge of the group's member and any one they suspected as Boko Haram supporter or sympathizers. Dozens of people were rounded up and executed without trial, Muhammed Yusuf was arrested by the army and handed over to the police, who killed him within hours and claimed that he was shot while trying to escape (Walker, 2012:4).

After the conflict with law enforcement agents, the remaining youth among the group went back to Maiduguri to join the other group lead by Mohammed Yusuf who was said to have embarked on an intensive and largely successful, in the recruitment of members such that he had over 500,000 members before his demise (Madike, 2011:2). Madike also alleged that Yusuf taxed each members one naira daily, meaning that he received about $\# 500,000$ per day for the welfare provided which includes school and mosque where many poor families from Nigeria and neighboring countries enrolled their children.

\section{Theoretical Framework}

There is no doubting the fact that theories of conflict and violence have dominated the literature as it relates to Boko Haram in Nigeria such as class theory of terrorism; Jihadism; theocratic Islamic states theories; conspiracy theory and many more, but all these did not individually explain reasons for the evolution of Boko Haram and its impact on business environment in Nigeria; they seem to have looked at the phenomenon from a single cause perspective. On the contrary, the theory of structural violence shall be used to help in the analysis of this paper.

\subsection{Structural Violence Theory}

The theory of structural violence states that some violence are avoidable but becomes inevitable due to deprivation of some basic human needs in the areas of political, socioeconomic and cultural structures, because those suffering from this deprivations are linked with the variables mentioned above by structural violence theorists. Structural violence may occur as a result of lack of human agencies which may make an action of a person to result to unequal distribution of resources.

Structural violence exists when some groups, classes, genders, and nationalities are assumed to have, and in fact do have, more access to goods, resources, and opportunities than other groups, classes, genders and nationalities, these unequal advantage is built into the very social, political and economic systems that govern societies, states and the world Galtung (1969). For a long time however, there tends to believe the government's inability to meet up with its responsibilities also leads to violence in societies such as that of the Boko Haram (Burton, 1997). The structural violence theory has its largest proponents from the intelligentsia, prominent amongst them are Johan Galtung (1969); and (Burton, 1997).

One of the schools of thought which blame socioeconomic conditions for the violence act such as those of Boko Haram activities in Nigeria is premised on the human needs/ structural violence theory. It argues that human beings have some basic needs to achieve and when the failure to do this is caused by somebody, it then leads to violence activities (Rosati et al, 1990 cited in Faleti:51). This theory is likened to that of frustration-aggression theory of violence, states "frustration is a product of aggression" (Dougherty and Pfaltzgrate Jnr, 1990: 266). 
The theory sees relative deprivation as the main difference between what one expects but unable to get which is seen as a gap between aspirations and achievement which brings about psychological state of frustration and aggressive attitudes coming out of such situation (Midlarsky, 1975:29).

It is further argued that Nigeria's socio-economic index seems to confirm the views of human needs/ structural violence theory. Nigeria ranked 16 out of 176 in 2013 on the index table where the socio-economic factors stands high as the reason for violence activities such as that of Boko Haram in Nigeria and particularly in the Northern part where unemployment among the youths; corruption; poverty; injustice; and a worsening standard of living is the order of the day.

In the interpretation of the Boko Haram's evolution and violence activities, the proponents of Human needs/structural violence theory admits that there is endemic poverty and hopelessness in Nigeria generally but more severe in the northern part of Nigeria. It was debated that "the root cause of violence and anger in both the north and southern part of Nigeria is endemic poverty and hopelessness; hence the Nigerian government was advised to address the socio-economic deprivation in the country which is most severe in the north (Herskovits, 2012).

Some scholars also reaffirm that the very high incidence of poverty in Nigeria is generally seen as a northern problem. The three northern regions have an average poverty incidence of $70.1 \%$ compared to $34.9 \%$ of the south's three. While the Southern part of Nigeria record the lowest poverty incidence, the Northern part has the highest with 70\% of the people living below $\$ 1$ per day, which is equivalent to N129 per day" (Lukman n.d.). Frustration as a result of economic deprivation may lead to violence in some developing countries (Dougherty and Pfaltzgrate, Jnr. 1990: 266). This is the present situation as currently taken place in Nigeria of today.

It is pertinent to argue that the north's socio-economic crisis lies in its system of patrimonial economic system, which disallow women from participation in economic activities, and the bad governance in Nigeria that places distribution above production (Aregbesola, 2012). Aregbesola further argued that the non participation of women in economic activities does not lead to violence and terrorism, yet, it is only the adult males that sustain that society; because, for the male to Sustain their family has become difficult, especially with the north no longer with political power at the center makes the Northern elites unable to meet up their demands which in turn makes it difficult for crumbs to go to the less privileged and hence, violence in the Northern part of Nigeria (Aregbesola, 2012).

Economically, there is competition for scarce resources which also play some role in the political violence in some developing countries (Oberschal 1969 and Nelson 1969). There is complaint from the Northern part of Nigeria claiming to be at disadvantage in the federal allocation structure, despite the prevailing illiteracy; poverty; and ignorance in that part of the country, this situation makes it difficult for the North to develop industrially and hence their engagement in violence activities (Daily trust, online, 2012).

Some argued that poverty and unemployment are not excuses for terrorist activities by Boko Haram because, other parts of Nigeria do experience adverse socio-economic conditions. The North West and North central also have beggars on their streets yet they did not use the poverty excuse to go into violence activities (People Daily, online, June 26, 2012).

From the above perspective therefore, it can be stated that, other factors such as religion contributed to the evolution of Boko Haram in Nigeria as explained in other theories, but not addressed in the Daltung structural violence theory, because not every socio-economically deprived individual will be motivated to lend support to acts of violence perpetrated by the Boko Haram insurgent group in Nigeria which has some devastating impact on the business environment in Nigeria and particularly the Northeastern zone.

\section{Research Method}

The method of data collection for this paper was that of qualitative one. Qualitative research is a method of inquiry that produces results in words rather than statistics (Bello, 2007). It is a research based on behavior; person's live functioning of organization, interaction between nations and cultural phenomenon (Straus and Corbin, 1998). This research adopted several approaches which include explanatory and historical approach of study with emphasis on documentary as well as library research. Particularly, the emphasis on sources of data for this study was premised on a historical research based on primary documents contextual study and analysis of documentary evidence. There shall include government documents and reports; legal documents such as cases of convicted members of Boko Haram and enacted laws on terrorism; documents from international organizations such as Amnesty International, Human Right Watch and United Nations; Newspapers and Magazines; speeches from government; and internet. 


\section{Findings}

To say that the deadly activities of the Islamic sect, Boko Haram are not killing the economy of the North is an understatement because the series of attacks has been going on due to the prevalence of Boko Haram in that region which made business men and companies with no options but to fold up and move out of that zone. Other areas where the activities of Boko Haram seriously affects business enterprises with businesses activities destroyed include: Yobe, Niger, Kaduna, Kano, Plateau, Kogi, Bauchi and recently, Sokoto (Adebayo, 2014).

It is also on record that frequent attacks between the insurgents and the police force brings about killing and destruction of property in the Northeast made people, particularly those from the southern parts of Nigeria to flew from that region for their lives with their business activities in that part of the country an abandoned ventures (Adejumola, and Tayo, 2012).

In Maiduguri, the capital city of Borno state, there is a popular market called Monday Market been the biggest market in the state, it was worse hit due to the attacks by the Boko Haram insurgents, the shops has to be closed because there were own by the southern people of Nigeria, in fact it was reported that over 10,000 were closed as a result of the activities of Boko Haram (Oshio, 2009).

Further findings proved that Banks no longer operate on normal working hours, due to the adverse effects of the attacks by Boko Haram, which led to the reduction of business hours for both the banks and their customers for the fear of their been attacked by the Boko Haram insurgent. The threat from Boko Haram and its resultant effects was buttressed by the Borno State Commissioner of Information, Mr. Inuwa Bwala, when he stated that "it will take the state over 20 years to recover from the current predicament the Boko Haram has created for the state" (Ome, and Ibietan, 2012) Another important Northern state equally affected by the activities of Boko Haram in the areas of business entrepreneurship is Kano state which has been the commercial centre as well as the economic base of the North prior to the emergence of even some neighboring countries such as Niger Republic, Chad and northern Cameroun as nations, but Kano today has been deserted with investors relocated with their businesses to other parts of Nigeria due to the security challenges perpetuated by the activities of Boko Haram (Okereocha, 2012).

It has been further discovered that about 80 per cent of the industries previously located in Kano are said to have closed down their factories, due to power failure as well as the daunting security challenges. More so, due to the security challenges created by the insurgents and its attending impacts on both private and public sectors of the economy has made many business men and traders to have relocated their businesses from the city of Kano (Sunday Trust, 2012).

It could also be recalled that the President Goodluck Jonathan's economic reform may not be of any significant benefit in Nigeria due to the threat to security perpetuated by the activities of Boko Haram which made foreign investors to abandon the area, because it is stated that without security, there can't be development (Baiyewu, 2012).

Another serious impact of the activities of Boko Haram as discovered in the findings of this study is in the areas of cost of doing business. Boko Haram insurgents has increased the cost of doing business by the private sectors as well as providing public services for the citizenry because resources that would have been invested in increasing output, funding of education, health and other welfare programmers are diverted to crime control and prevention. As stated by the Nigeria's Finance Minister, Dr. Ngozi Okonjo-Iweala, key allocation of funds in the 2013 budget include: Critical infrastructure (including power, works, transport, aviation, gas pipelines, and Federal Capital Territory) - N497 billion; human capital development (i.e. education and health) - N705 billion; and agriculture/water resources - N175 billion. Also over N950 billion for was allocated for national security purposes, comprised of N320 billion for the Police, N364 billion for the Armed Forces, N115 billion for the Office of the NSA, and N154 billion for the Ministry of the Interior (This Day, 2013).

The above analysis is a situation where the funds allocated to security alone is almost equal to funds allocated to education, health and critical infrastructure combined in a fiscal year; this is detrimental to national development. The development of a society largely depends on the rate of crime. If the crime rate is high, it always scares away or discourages investors from coming to Nigeria to do business (Adebayo, 2013).

It was also reported that due to the activities of Boko Haram and other challenges in the country made youths to be left unemployed because of the inability of the industries to operate made it possible for numbers of youths to available to be recruited by the Boko Haram insurgents. In 2009 alone, some industries were unable to remain in production, while other remaining ones managing to operate are been classified as "ailing", a situation that poses serious threat to the survival of the manufacturing sector as well as the business environment in the country. Many of these firms that collapsed or closed operation are regarded to be as a result of factors such as insufficient availability of power supply among other factors (Okafor, 2011). 
Boko Haram insurgents became too sophisticated and frequent in its attacks to the extent that the U.S. Embassy in Nigeria decided to warn its citizens concerning the prevailing security situation in the country. It further advice them to avoid some major hotels in Abujaa (U.S. Embassy, Nigeria, 2011). With this type of signal, interested investors won't like to visit Nigeria for business any longer.

\section{Recommendations and Conclusion}

From the forgoing therefore, it could be argued that business and entrepreurship can only succeed in a peaceful atmosphere. In view of the above, serious strategies is highly needed in combating the menace of the Boko Haram insurgent in Nigeria, because the effect of the insurgent is not conducive for business activities.

The present economic situation in Nigeria where it only relies on a mono economy and its subsequent reliance on foreign investment would worsen the situation arising from the present Boko Haram insurgent. There is no gain saying about countries becoming economically strong and viable globally business wise and it would be said that theyare under an unsecured environment as being experienced in Nigeria today, and so people and government of Nigeria need to be worried concerning the low level of business and entrepreneurship in Nigeria. For this reason therefore, serious strategies need be put in place to change things positively to be able to improve on investment and industrial growth of the nation.

Boko Haram along with other crime vices have created negative impact in the society that there are fear in the people which led to reduction in the country's growth and development in business and entrepreneurship. This menace need to be dealt with by the government mainly through blocking sources of funds, training and weapon supply of Boko Haram group and most importantly human security must be adequately handled.

It could be recalled that insurgency is alien to the Nigerian security, because the military are only trained for convention wars and not asymmetric ones such as that of Boko Haram and hence, they deserve training to include that of how to handle terrorism and insurgency cases. The laws on terrorism need to be reviewed to the extent that offenders must be duly punished for offences concerning insurgency and terrorism.

The Nigeria border needs to be properly protected because most of the recruited members of Boko Haram are from the neighboring countries. More so, there is the issue of intelligence report, there is also the need for serious improvement on intelligence to enable any criminal vices such as Boko Haram to be prevented instead of finding ways of combating it.

The government of Nigeria should evolve means of reducing poverty, so that people's lives can be improved upon, particularly youths. Government should be able to make provisions for the citizens in the area of social welfare and creation of job opportunities which are necessary for happy people with relative prosperity which are necessary agents for national security.

Employment of youths must be taking seriously by government because the youths are readily available for recruitment for there is the need to reduce unemployment so as to deprive groups such as Boko Haram from getting those to be recruited into their group. From all indications, creation of jobs for the youths will bring about reduction in crime, and hence a boast in sustainable business entrepreneurship environment.

All government functionaries at all levels must abstain from corrupt practices while fighting crime and insurgents. If not for the activities of Boko Haram, all forms of development would have been well harnessed, but now, resources are concentrated mainly at the federal and state government for combating Boko Harm instead of provision of social facilities for the welfare of the people.

Another sector that should be taken seriously should be education; it should be all encompassing in Nigeria. Government should as a matter of must carry the Almajiri system in the North along educationally so as to enable children in that zone to be seen to be useful to the society and themselves in particular. More so, education should be made free and mandatory for all children in Nigeria.

From the foregoing, it could be stated that the insurgents has given Nigeria bad publicity, and adversely affects its business size, with investors discouraged from investing in the country. It further reduces the national funds that would have been used for business by the government to avoid the threat to lives and property in the Northeast Nigeria and Nigeria in general, all have brought the non improvement in the area for business and entrepreneurship which are of highly need in Nigeria.

\section{References}

Adesoji, A. (2010). "The Boko Haram Uprising and Islamic Revivalism in Nigeria", in Africa Spectrum, 45(2): 95-108

Adejumola, A.S. and Tayo-Olajubutu, T.O. (2009). Spinning off an Entrepreneur Culture among Nigerian University Students: Prospects 
and Challenges. African Journal of Business Management. 3(3), pp. 80-88.

Adebayo, A.A. (2013a). Youths' Unemployment and crime in Nigeria: A nexus and implications for national development. International Journal of Sociology and Anthropology, 5(8), pp. 350-357.

Aregbesola, R. Paper Presented at the National Symposium on 'Islam and Peaceful Co-Existence in Contemporary Multi-Religious State' at the Shehu Musa Yar'Adua Centre, Abuja, May 15, 2012.

Burton, J. (1997). Violence Explained: The Sources of Conflict, Violence and Crime and Their Provention. Manchester: Manchester University Press.

Baiyewu, L. (2012) "Boko Haram, Bad Signal to Foreign Investors, Sunday Punch, January 29, P.9.

Chothia, F (26 th August,2011). "Who are Nigeria's Boko Haram?" BBC News, Online at: http://www.bbc.co.uk/news/world-africa13809501. Retieved, 10/11/2013

Dougherty E.J and Pfaltzgrate Jr, L.R. (1990). Contending Theories of International Relations: A Comprehensive Survey, second edition. New York: Harper \& Row Publishers,

Eme, O.I. and Ibietan, J. (2012). The Cost of Boko Haram Activities in Nigeria. AJMBR Vol. 2(2).

Faleti, A.S. "Theories of Social Conflict," in Best, G. S (ed). Introduction to Peace and Conflict Studies in West Africa. Ibadan: Spectrum Books Limited, 2006.

Galtung, J. (1996). Peace By Peaceful Means: Peace, Conflict, Development and Civilization. Thousand Oaks: Sage Publications.

Gusau, I. U, (2nd August, 2009) "Boko Haram: How It All Began," Daily Trust, Onlineat:http://sundaytrust.com.ng/index.php?option=com _content\&view=article\&id=825:boko-haram how-it-all-began-\&catid=3:peoplein-the-news\&ltemid=110.

Herskovits, J. ( January 4, 2012). between-herskovits-azazi-and-jonathanhttp://www.vanguardngr.com/

Lukman,S.M.(n.d.TheNorthandthePovertyPhenomenon.http://www.gamji.com/article6000/NEWS6707.htm

Midlarsky, M. (1975). On war. New York: The Free Press Midlarsky, M. (1975), On war. New York: The Free Press

Madike, I. (June 19th 2011). BokoHako Rise of a deadly sect, National Mirror, http://www.national mirror/bog-red/1458.html.Retrieved 2:04:13.

Mantzikos, L. (2010). The Absence of a State in Northern Nigeria: The case of Boko Haram African Renaissance Vol. 7 No 1, 57-62.

Onuoha, F.C.(2010). "The Audacity of the Boko Haram: Background, Analysis and EmergingTrend. Security Journal, 25(2), 134151.doi:10:1057/sj.2011.15

Oberschall, R. A.(1969). "Rising Expectations and Political Turmoil." Journal of Development Studies.

Okereocha, C. (2012), "Heartache for the Economy", TELL, May 14, Pp. 46 - 47

Oshio, E. (2009). The Challenge of National Security and Development. Being a paper delivered at the Delta State Christia Professional League Seminar on Crisis Management and Nation Building at Grand Hotel, Asaba.

Okafor, E. E. (2011). Youth Unemployment and Implication for Stability of Democracy in Nigeria. Journal of Sustainable Development I Africa, 13(1), 358-373.

Reuters, (21 September 2013). "Islamists claim gun attack on Nairobi mall, at least 39 dead". Retrieved 22 September 2013. This Day live.com/articles/2013 Budget and Nigeria's Fiscal Consolidation Target. Retrieved on 20/5/13

Walker, A. (2012)." What is Boko Haram? US Institute of Peace, Special Report. www. USIP. Org. office of the coordinator for counter terrorism, country Report on Terrorism. 
